\title{
Student Management at Saint Aloysius School Dormitory
}

\author{
Antsa Rinaldi Rafaliarisoa, Cepi Safruddin Abdul Jabar \\ Universitas Negeri Yogyakarta, Yogyakarta, DIY, Indonesia
}

Corresponding author: Cepi Safruddin Abdul Jabar (e-mail: cepi_safruddin@uny.ac.id)

\begin{abstract}
This study aims to obtain an understanding of the student management at the Saint Aloysius school dormitory in the Special Region of Yogyakarta, Indonesia. The research applied a case study research method. It mainly involves the participation of four caretaker team members and ten students. The obtained data were collected through techniques, such as interviews, observations and document analysis. The research study involves the application of three concurrent data analysis techniques. The research led to the knowledge and the understanding that despite the dormitory's geographical location and its small size, the caretakers at the involved school dormitory make an effort to provide most of the services and tasks required for an effective student management.Generally, the student management implemented at this specific school dormitory involves the establishment of different tasks and services. Important factors, including staff supervision and training, the establishment of the formal program, also need to be considered by the caretakers. Caretakers still need to make some effort to improve management services.
\end{abstract}

Keywords: student management, school dormitory, caretakers

\section{Manajemen Kesiswaan di Asrama Sekolah Santo Aloysius}

\begin{abstract}
Abstrak: Penelitian ini bertujuan untuk memperoleh pengetahuan yang mendalam berkaitan dengan manajemen kesiswaan di asrama SMP Santo Aloysius di Daerah Istimewa Yogyakarta. Metode penelitian menggunakan pendekatan kualitatif dengan jenis studi kasus. Pada penelitian ini, melibatkan partisipasi dari empat anggota tim pengasuh asrama dan sepuluh siswa asrama. Data yang diperoleh dikumpulkan melalui beberapa teknik, seperti wawancara, observasi dan analisis dokumen. Studi penelitian melibatkan penerapan tiga teknik analisis data secara bersamaan. Penelitian ini menunjukkan pada pengetahuan dan pemahaman bahwa terlepas dari lokasi geografis asrama dan ukurannya yang kecil, pengasuh asrama sekolah harus terlibat melakukan upaya untuk menyediakan layanan yang diperlukan untuk manajemen siswa yang efektif sebaik mungkin. Secara umum, manajemen kesiswaan yang diterapkan di asrama sekolah ini melibatkan pembentukan berbagai tugas dan layanan. Melalui diskusi tentang faktorfaktor penting, pengawasan staf dan pelatihan, serta membuat program yang bersifat formal, juga perlu dipertimbangkan oleh para pengasuh asrama. Dengan demikian, pengasuh asrama masih perlu melakukan upaya untuk meningkatkan layanan manajemen.
\end{abstract}

Kata kunci: manajemen kesiswaan, asrama sekolah, pengasuh asrama 


\section{INTRODUCTION}

Nowadays, there exist a considerable number of boarding schools in Indonesia. In the province of Yogyakarta, dozens of boarding schools accessible to the local students and those from outside. Those educational institutions range from very prestigious boarding schools, which are categorized as international schools, to non-profit ones. Also, most of them are categorized as Islamic or Christian boarding schools which can be considered as full or semi- boarding schools.

According to some research studies, such as the ones conducted by Curto \& Fryer (2012), Behaghel, Chaisemartin, \& Gurgand (2015), Bass (2014), White (2004) and Martin et al. (2014), boarding schools can be generally considered as appropriate places where parents can send their children in order to receive a quality education. In other words, those educational institutions are supposed to have positive impacts on students' academic and non-academic performances. This success depends on the conduciveness of the boarding school environment, which is closely related to the quality of boarding student management, especially in the dormitories.

The research is focused on the case of the management of some students at a Coeducational Catholic boarding school dormitory which can be considered as still in full expansion. That educational institution is located in a village called Turi, situated outside the city of Yogyakarta. Also, the target school dormitory is a part of Saint Aloysius Turi Middle School, which can be considered as a semi-boarding school.

It could be noticed that the previously described school dormitory faces different problems related to the students' academic performance and learning engagement, financial management and facilities. In addition, the dormitory caretakers appear to be not satisfied yet with the quality of their student management, an issue which has become the main focus of this research.

As such, the research study aims to obtain an understanding of the student management of the boarding students at Saint Aloysius Turi Middle School dormitory. Not only can this study be considered as an act of assistance to the dormitory caretakers to help them improve the quality of the student management but also it is expected to strengthen the existing theories concerning student management, especially the ones related to dormitory or boarding schools. On the other side, it has an impact on the effectiveness of the learning process carried out in a boarding school. 


\section{METHOD}

The conducted research study employed a qualitative research approach. The research mainly aims to obtain an studentunderstanding of student management at the Saint Aloysius Turi Middle School dormitory related to the issue in question. As such, it involves the use of a case study research method.

The research involves the use of three data collection techniques, including (1) interactive interviewing, (2) observation and (3) documentation. More precisely, all the points included in the research involved shorter case study interviews with both the dorm caretakers and the boarding students. The interviews conducted mostly involved openended questions. Also, the conducted interviews involved four caretakers added to ten boarding students selected on purpose due to their responsibilities at the dormitory.

It should be mentioned that after or before any interview, a general observation has been conducted. For instance, observations were conducted in order to confirm evidence concerning the students' accommodation organization, students' characteristics, the monitoring of the boarding students' academic learning progress, disciplinary control condition at the dorm, the education style applied at the dorm and the organization and condition of the boarding students' sections, moral education, spiritual education and some students' welfare programs, such as health care, nutrition service, safety and the recreational program condition that were obtained from the interviews.

Some document analysis has also been effectuated. More precisely, administrative documents including the caretakers' respective responsibilities and students' extracurricular activities schedule, students' official daily schedule, and some personal data about each boarding student have been made available. Apart from those documents, some pictures are taken from the observations also used as supporting documents.

Those techniques also used to confirm the validity and credibility of the findings obtained from the interview sessions. The triangulation of sources involving different respondents has been put into practice in the research.

The analysis of the obtained data involves some flows of activity suggested by Miles, Huberman, \& Saldana, which includes the conduct of three (3) concurrent activities. These activities include (1) data condensation, (2) data display and (3) conclusion drawing and verification (Miles, Huberman, \& Saldana, 2014, pp.12-14). 


\section{RESULTS}

\subsection{Student management in school dormitory}

\subsubsection{School dormitory services}

The services provided by the dormitory caretakers to the Saint Aloysius dormitory students can be considered as quite complete. The research led to the conclusion that the student management implemented at the dormitory involves the establishment of different services, which can be classified into three categories including, firstly, the (1) new student service which includes tasks, like the student admission, including three main selection steps involving both school and dormitory staff. Also, it includes some accommodation service which is organized according to the students' gender and class level. Moreover, that category of management involves the establishment of a new student orientation service which involves the participation of senior students generally.

Secondly, it involves the (2) management of the educational process which includes the monitoring of the academic learning progress, effectuated thanks to a supervised evening learning session. Then, it includes the establishment of a disciplinary control system, involving a strict schedule and regulations. Moreover, that educational process management includes the provision of guidance and counseling service, involving some important elements related to the students' education, which is based on the students' characteristics. Also, it includes the implementation of some services related to the students' welfare.

Thirdly, it includes the (3) evaluation and reporting of the students' academic learning progress and their adjustment to the dorm life. Those evaluations are reported to be scheduled and generally involve the participation of all the caretaker team members. The students' learning progress is reported to the parents via social media, and in organized meetings at the dorm.

\subsubsection{Management of school dormitory services for students}

The management function is applied in the student personnel management of the Saint Aloysius dormitory students, even though their application is not always effectuated as it is expected. In the planning case related to the engagement of the students in some of the dormitory services, which mainly involved one of the senior caretakers to create the different students' sections. In fact, the reason why that respondent became in charge of the planning of such a field was the fact that he was the one who had the inspiration. 
Consequently, he has been allowed to plan everything needed to concretize the idea in question. It shows that the planning process of the services or the activities at the dormitory can be considered as very flexible.

In addition, the organization and the supervision of the services and the activities at the dormitory are quite flexible since there is no strict rule or regulation which dictates the way how those functions should be effectuated. More precisely, For instance, as far as the organization of the caretaker members' supervision is concerned, it is effectuated in a quite informal or natural way. For instance, as far as the sharing of the caretakers' tasks is concerned, each member of the team is allowed to choose their students' evening learning sessions or the students' daily activities supervision schedule in general. In addition, as they work as a team, whenever any caretaker in service happens to be unavailable for the supervision of the students, based on their planned schedule, the other caretakers would help and replace the unavailable ones.

Finally, the evaluation of the students' learning progress involves the caretakers to evaluate the dorm students' academic learning progress and their adjustment to dorm life. Those evaluations are reported to be usually scheduled in advance. They generally involve the participation of all the caretaker team members in organized meetings focusing on the evaluation of the progress of the students, especially those who are in difficulty and the resolution of the latter's problems, which are usually followed by trials. Unfortunately, it has been noticed that the caretakers rarely control the academic learning progress of the students on purpose, despite the existence of the evening learning sessions. Generally, they would wait for the reports from the school staff. The fact that some caretakers are also school staff is one of the reasons for such a decision. Also, not only do they rarely evaluate their services, including the welfare ones, but they do not also have any clear and systematic measurement approach to do it.

\subsection{The effectiveness of student management in school dormitory}

The dormitory has a clear vision and missions which have becosme the basis of the education provided to the students. As such, the caretaker team make an effort to provide the students with a complete education, which aims at optimizing the students' personal, social, spiritual, emotional and intellectual development. Consequently, the caretakers, inspired by a senior caretaker, made an effort to involve the students directly in the 
management of their activities and some services provided by the dormitory, because the creation of the students' sections which aim at training them to become independent and responsible, thus competent adults.

Besides, the fact that the caretakers involved the students in the updating process of the dormitory regulations can also demonstrate the caretakers' care for the students' good and needs and especially their consideration of the vision and missions chosen. Also, the caretakers' consideration of the importance of the application of such a learnercentred strategy can be shown by the fact that the caretakers not only try to educate the students with flexibility, tactfulness and patience but also make an effort to solve the students' problems case by case involving the students' parents. Finally, the provision of evening learning session every day to the students can be considered as an excellent initiative which is based on the students' academic needs.

\subsubsection{Relationship between the caretakers and the students}

Based on the findings, the students have a quite close relationship with the caretakers, particularly with two of them. It has been observed that not only the students do not hesitate to complain to the caretakers whenever they face any problem, but they even dare to ask for an extra snack to some caretakers. It can be concluded from the fact that the caretakers try to educate the students as their children, a decision which requires them to know the students personally.

Besides that, the caretakers also appreciate the students as they are. For instance, this is because the caretakers rarely, or even never, force the students to participate in extracurricular activities that the students do not appreciate. Consequently, the caretakers created some activities proper to the dormitory students, such as farming and gardening, based on the students' interests. The caretakers show some flexibility and patience towards the students can demonstrate their consideration of the students, as youngsters in difficulty, who need to be taken care of in a particular way.

\subsubsection{Students' academic motivation}

The studentcaretakers do not fully accomplish the students' academic motivation at the Saint Aloysius school dormitory. More precisely, such conclusions can be drawn from the condition of the students' academic results, which can be considered as not satisfactory yet. Also, the fact that the caretakers in service do not evaluate or check the 
students' academic progress by themselves on purpose, despite the existence of evening learning sessions, shows their lack of interest in such a field.

\subsubsection{Moral and discipline improvement}

Based on the findings, caretakers at the concerned dormitory starts to succeed in improving the moral and discipline of the students. Such an improvement can be concluded from the fact that the caretakers receive less bad reports from the school concerning the students' behavior. In addition, the fact that the caretakers could let the students accomplish some activities without direct supervision sometimes can also show the improvement of the students' discipline. Finally, the decrease of aggressiveness and bad temperament from the students from specifically form the eastern part of the island, thanks to the particular intervention of one of the caretakers, can show such an improvement.

3.2.4 Development of students' sense of responsibility and ethical tolerance

It should be mentioned that the improvement of the students' discipline and moral is due to the kind of education style applied at the dormitory, which is based on flexibility, tactfulness, patience and especially on a religious theory which strengthen tolerance. Such an education style has been noticed to create students' understanding and appreciation of the importance of fairness and ethnical tolerance. In addition, the caretakers offer the students the opportunity to be involved in the formulation of the dormitory regulations

\subsubsection{Dormitory services program}

Even though the dormitory caretakers do not have any formal or written program available, the results of the services that they provide show that they have some "informal program", resulted from some planning and diagnosis mainly effectuated by the senior caretakers, which is shared with the rest of the team. For instance, those results include the creation of the students' sections, the engagement of the students in some services and activities' management and the initiative to solve the students' psychological problems case by case. However, such a working style might be considered as one of the deficiencies of student personnel management in the dormitory. 


\subsubsection{Welfare services}

The caretakers at this particular dormitory try to provide all the necessary welfare services, including accommodation, guidance and counselling, nutrition, health, safety and recreational service, which are meant to promote students' welfare. As such, compared to the contents of the different lists of student personnel management tasks or services suggested by experts, the services provided at the St. Aloysius School dormitory is quite complete.

However, despite the completeness of the services provided, the service quality has been noticed to be less satisfactory. On the one hand, the recreational and extracurricular activities provided at the dormitory are seen to be well-organized and involve the participation of the students in their organization result in the stimulation of the students' loyalty

\subsubsection{Staff supervision and training}

Based on the findings, such as supervision from the head of the dormitory does not exist. Informally as such, the supervision of the dormitory caretakers at this particular dormitory still needs some improvement. Also, it can be mentioned that the caretakers at St. Aloysius dormitory experience the same challenge as some caretakers in some Australian boarding school related to their lack of skill-based training.

\section{DISCUSSION}

\subsection{Student management in school dormitory}

\subsubsection{School dormitory services}

The services provided by the dormitory caretakers to the Saint Aloysius dormitory students can be considered as quite complete generally compared to the reports of some researchers on boarding school services for students conducted by Yue, Shi, \& Chang et al. (2012), Luo, Shi, \& Zhang et al. (2009) and Gatua (2015). In other words, it has been noticed that Saint Aloysius Turi Dormitory makes an effort to try to provide its students with student personnel services, such as intellectual, psychological, social, guidance, nutrition and health services, which are required from them. As such, it can be concluded that at least such a dormitory applies student management.

Based on the findings, it has been noticed that the student management implemented at Saint Aloysius Turi dormitory can be described as Mulyasa (2003, p.46) 
and Nosiri (1985) (as cited in Nwakpa, 2015, p.62) defined the term student management theoretically. First, this is because according to the research findings, the concerned dormitory provides the students with different kinds of services and supports from their first arrival at the dormitory until their graduation, a fact which matches with Mulyasa's definition.

In addition, the variety of the services provided at Saint Aloysius Turi dormitory can be related to the definition of student personnel management suggested by Nosiri (1985) (as cited in Nwakpa, 2015, p.62), who views such a kind of personnel management as including supervising and administrative functions, added to any services different from classroom instruction. This is because the student management implemented at such a dormitory involves some administrative functions principally effectuated by the head of the dormitory, some supervising functions effectuated by the caretakers in service, in turn, every week and other services which are specially related to the students' general well-being, such as recreational, health and guidance and counselling services.

As such, the services included in the student personnel management implemented at that specific dormitory involve non-instructional services or activities which are actually meant to help the students achieve their educational objectives. In other words, the education provided by the caretakers through coordinated services aims to transform those broken children into youngsters who are full of life and well-disciplined. Such a finding also partially matches with Ezeocha's (1990) (As cited in Chidobi, 2015, p.2104) and Wilson's (1966, p.596) definition of the term which explains that student management also involves coordinated non-instructional services which aim at optimizing students' intellectual, psychological, social and physical development.

\subsubsection{Management of dormitory services for students}

As the student personnel management is still a part of educational management in general, it also requires the involvement of some functions of management such as the ones included in Emetaron's (2002) (as cited in Nwakpa, 2015, p.62) definition including planning, organizing, supervising, coordinating and the controlling. It can be mentioned that those management functions are applied in the student personnel management of the Saint Aloysius dormitory students, even though their application is not always effectuated as it is expected. 
In other words, for instance, as far as the planning of the services and activities are concerned, they are said to be effectuated by the caretaker team members whenever any adjustment is needed to be done. As such, the planning of the services is not under the responsibility of the dorm head only; any member of the team can take part in it. Nevertheless, in the evaluation activity, unlike some Finnish welfare service organizations which are quite active in their performance measurement (Sillanpaa, 2011), they rarely evaluate their services, including the welfare ones. They do not also have any clear and systematic measurement approach to do it.

Besides, it has been noticed that no one controls the services provided by the caretakers, apart from the students' parents. The interview results led to understanding that the caretakers do not have to report the student condition and the progression of the student personnel management to anybody or any higher authority in their congregation. Usually, they would provide the students' parents with some reports concerning the students' life conditions at the dormitory and school as often as possible via telephone or WhatsApp or would organize a meeting at the dormitory with the parents to directly talk about any new projects suggested by the caretakers or any bad or good circumstances related to the services and the learners' progress. Thus, it can be concluded that the caretaker team members control their services and duties by themselves and among themselves.

\subsection{The effectiveness of student management in school dormitory}

The dormitory has a clear vision and missions. It is worth mentioning that such vision and the missions have been created primarily for the students, a fact which can be considered as an illustration of Emetarom's (2002) statement about the primary objective of the educational institution's existence. The caretaker made an effort to involve the students directly in the management of their activities and some services provided by the dormitory. However, despite these remarkable efforts effectuated by the dorm caretakers, the concerned boarding school is still far from being considered as an elite one since it has none of the five identified characteristics of an elite boarding suggested by Fernandez (2009).

According to Ukeje (1994) (as cited in Nwakpa, 2015, p.62), there exist seven (7) points which can become the objectives of the establishment of student personnel 
management in an educational institution. The comparison of those objectives mentioned below, and the real condition of the student personnel services implemented by the Saint Aloysius school dormitory caretaker team is also aimed to provide a general image of the probable effectiveness of their services.

\subsubsection{Relationship between the caretakers and the students}

First, the first objective suggested by Ukeje, which can also be related to one of Nwakpa's (2015) points about the importance of the establishment of effective interpersonal communication between school staff and students, have been observed and reported by both the interviewed caretakers and students. The students have a quite close relationship with the caretakers. Nevertheles, Nwapka's (2015) suggestion, which requires school administrators to appreciate, understand and accept students as they are, can be considered as one of the means that can lead to the achievement of the first objective discussed previously. That requirement has been noticed to be quite well respected by the caretakers.

Moreover, the establishment of effective interpersonal communication between school administrators themselves is highly required so that student personnel management can be effective (Nwakpa, 2015). It should be mentioned that the situation at the Saint Aloysius school dormitory shows that the caretakers have a very good relationship among themselves. The fact that they work as a team also demonstrates that good communication among the caretakers. As such, it can be mentioned that the "horizontal communication" among administrators discussed by Shear, B. (1965, p.137) exists in the dormitory.

\subsubsection{Students' academic motivation}

Then, as far as the second objective suggested by Ukeje (1994) (as cited in Nwakpa, 2015:62) concerning the increase of students' interest in academic learning is concerned, unfortunately, it is not fully accomplished by the caretakers at the Saint Aloysius school dormitory. Moreover, it can be concluded that the situation of the academic result of the students at this specific dormitory does not support Martin', Papworth, \& Liem's (2014) and Curto, \& Fryer's (2012) findings which demonstrate that boarding school can affect students' academic motivation. Based on the finding, especially in the field of students' academic results, the student's academic motivation is not satisfactory yet. However, the 
gain of academic self-efficacy requires serious assistance and nurture of academic motivation (Scheel, Madabhushi, \& Backhaus, 2009).

\subsubsection{Moral and discipline improvement}

In addition, the positive results of the education style applied at the dormitory support Martin, Papworth, \& Liem, G's (2014) findings about the fact that boarding schools can positively affect students' engagement and well-being. The caretakers at the concerned dormitory start to succeed in improving the moral and discipline of the students. This is mainly because differently from the education condition discussed by Ramey (2015), and Mary-Day, (2017), the caretakers at the concerned dormitory make an effort to "medicalize" the students through behavioral intervention and try to understand behavioral problems' causes before applying suspensions or expulsion. Also, it is thanks to the caretakers' effort to implement the scheduled guidance and counselling activities as opposed to the condition of such a kind of program in some schools in Kenya (Ruttoh, 2015).

Nevertheless, the moral and discipline of the students were improved. Such good results can illustrate the "modest positive" difference between boarding students and day students found out by Martin et al. (2014). Also, it confirms the belief of some school counsellors and students in some schools in Zimbabwe about the fact that guidance and counselling service can provide personal and social benefits (Chireshe, 2011).

\subsubsection{Development of students' sense of responsibility and ethical tolerance}

The improvement of the students' discipline and moral is due to the kind of education style applied at the dormitory. The caretaker involves students in the formulation of the dormitory regulation. It has also been reported and observed that, as opposed to some students in China (Zhao, 2011), they are not "passive participants". The involvement gives an opportunity to students to engage individually and collaboratively in managing some of their activities and dormitory services. It leads to the improvement of students' moral and discipline. It also provides students with such management skills as problemsolving abilities, leadership and sense of responsibility, which are in line with Srivastava and Singh's research findings (2013). The dormitory is more like a skill-based organization (Paletta's research, 2011). However, the involvement is not yet encouraging students to engage in managing school meals. This finding is different from other studies (see Tikkanen,2009). 


\subsubsection{Dormitory services program}

The provided service quality does not result in serious complaints from the students, similarly to the condition of some students in some dormitories in Iran (Khajehzadeh, 2016). Nevertheless, the provision of a quality of service, based on a well-prepared program, is essential to stimulate learners' loyalty and behavioral intention (Khoo, Ha, \& McGregor, 2017).

\subsubsection{Welfare services}

The caretaker had provided all the necessary welfare service as it is required by Nwakpa (2015) and Shear (1965, p.137). Even so, the quality of the management service is less satisfactory, the recreational and extracurricular activities provided at the dormitory are seen to be well-organized. As Ehigie and Taylor report it, (2009), this condition can give the stimulation of the students' loyalty. Unfortunately, differently from the findings of Chan (2016) and Piche et al. (2015), the practice of the extracurricular activities fails to improve the students' academic performance and learning style.

On the other hand, meals and health care are provided. Howewer, the quality of these services is not as good as the nutrition and health services at some schools in Shaanxi (Yue et al.'s, 2008) and other schools as reported by Pucher et al. (2013) and Pavletic et al. (2016). Further, the safety is doubting despite the use of CCTV and the presence of permanent caretakers at the dormitory area. This is because there are no security guards employed. However, this safety condition is not as poor as other found in some school dormitories in Kenya (see Gatua's article, 2015).

\subsubsection{Staff supervision and training}

In addition, as it is mentioned by Chidobi, (2015, p.2108), the existence of serious supervision of staff from the leader is also crucial for the effectiveness of the student personnel management. However, unfortunately, such supervision from the head of the dormitory does not exist. Generally, the supervision of the caretakers' services is effectuated by a mentor caretaker, who considered himself as a supporter, similarly to the mentor teachers' perception in Clarke et al.'s findings (2015).

Apart from the staff supervision, the concerned dormitory also lacks qualified caretakers who are supposed to have competencies related to the specificity of the dorm or boarding school, such as the ones suggested by Uhbiyati (2015). Also, the caretakers 
at St. Aloysius dormitory experience the same challenge as some caretakers in some Australian boarding school related to their lack of skill-based training which is considered to be vital (Hodges et al., 2013).

\section{CONCLUSION}

The research led to the knowledge and the understanding that first, despite the dormitory's geographical location and its small size, the caretakers at the involved school dormitory make an effort to provide most of the services and tasks required for an effective student personnel management as well as they can. The student management implemented at dormitory involve the establishment of different services. In other words, the student management at Saint Aloysius Turi Middle School dormitory involves the caretakers in service to establish different tasks and services involved in the (1) new student management, (2) educational process management and (3) the evaluation and reporting of the students' learning progress. Second, management of the educational process effectuated thanks to a supervised evening learning session. Establishment of a disciplinary control system included. Third, evaluation and reporting of the student's academic progress and their adjustment to the dorm life.

The establishment of those services led to some positive results in the students' education. This fact is due to the existence of strong teamwork and commitment from caretakers and the involvement of students and parents especially in the educational process management and the evaluation stage, which can be considered as key factors to student management effectiveness.

However, some other important factors, including the supervision of the staff, staff training, the establishment of a formal program or curriculum and program evaluation, also need to be considered by the dormitory caretakers. Apart from that, it should be mentioned that some services provided by the caretakers are not managed appropriately yet. As a result, the Saint Aloysius dormitory caretakers still need to make some effort to improve the management of some services, especially the academic learning support that they provide to the students. 


\section{Acknowledgement}

This research received no specific grant from any funding agency in the public, commercial, or not-for profit sectors.

\section{REFERENCES}

Bass, L. R. (2014). Boarding schools and capital benefits: Implications for urban school reform. The journal of educational research, 107(1), 16-35. doi: https://doi.org/10.1080/00220671.2012.753855

Behaghel, L., Chaisemartin, C. \& Gurgand, M. (2017). Ready for boarding? The effects of a boarding school for disadvantaged students. American Economic Journal, 9(1), 140-164. doi:10.1257/app.20150090

Chan, Y. (2016). Investigating the relationship among extracurricular activities, learning approach and academic outcomes: a case study. Active Learning in Higher Education, 17(3), 223-233. doi: https://doi.org/10.1177/1469787416654795

Chidobi, R. U. (2015). Management of student personnel service in public secondary schools in Enugu Education zone for sustainability of quality human resources for national development. International Journal of Scientific, Engineering Research, 6 (7), 2103-2109.

Chireshe, R. (2011). School counsellors' and students' perceptions of the benefits of school guidance and counselling services in Zimbabwean secondary schools. Journal of Social Sciences, 29(2), 101-108. doi: https://doi.org/10.1080/09718923.2011.11892960

Clarke, M., Killeavy, M., \& Ferris, R. (2015). Mentor teachers as leaders and followers in school-based contests in the Republic of Ireland. International Journal of Educational Management, 29(3), 368-379. doi: https://doi.org/10.1108/IJEM-092013-0142

Curto, V. E., \& Fryer Jr, R. G. (2014). The potential of urban boarding schools for the poor: Evidence from SEED. Journal of Labor Economics, 32(1), 65-93.

Day, A. M. (2017). Hearing the voice of looked after children: challenging current assumptions and knowledge about pathways into offending. Safer Communities, 16(3), 122-133. doi: https://doi.org/10.1108/SC-01-2017-0003

Ehigie, B., Taylor, M. (2009). Managing students' loyalty to school after graduation through relationship marketing. The TQM Journal, 21(5), 502-516. doi: https://doi.org/10.1108/17542730910983416

Gaztambide-Fernández, R. (2009). What is an elite boarding school?. Review of Educational Research, 79(3), 1090-1128. doi: https://doi.org/10.3102\%2F0034654309339500

Gatua, J. W. (2015). Assessment of safety status of physical infrastructure (classrooms, dormitories, sanitation facilities, laboratories and kitchen) in public secondary schools in Nairobi West Region, Kenya. Assessment, 5(3), 1-9.

Hodges, J., Sheffield, J., \& Ralph, A. (2013). Home away from home? Boarding in Australian schools. Australian Journal of Education, 57(1), 32-47. doi: https://doi.org/10.1177\%2F0004944112472789

Khajehzadeh, I., \& Vale, B. (2016). Shared student residential space: a post occupancy evaluation. Journal of Facilities Management, 14(2), 102-124. doi: https://doi.org/10.1108/JFM-09-2014-0031 
Khoo, S., Ha, H., \& McGregor, S. L. (2017). Service quality and student/customer satisfaction in the private tertiary education sector in Singapore. International Journal of Educational Management, 31(4), 430-444. doi: https://doi.org/10.1108/IJEM-09-2015-0121

Luo, R., Shi, Y., Zhang, L., Liu, C., Rozelle, S., \& Sharbono, B. (2009). Malnutrition in China's rural boarding schools: The case of primary schools in Shaanxi Province. Asia Pacific Journal of Education, 29(4), 481-501. doi: https://doi.org/10.1080/02188790903312680

Martin, A. J., Papworth, B., Ginns, P., \& Liem, G. A. D. (2014). Boarding school, academic motivation and engagement, and psychological well-being: A largescale investigation. American Educational Research Journal, 51(5), 1007-1049. doi:https://doi.org/10.3102\%2F0002831214532164

Miles, M. B., Huberman, A. M., \& Saldaña, J. (2014). Qualitative data analysis: A methods sourcebook. 3rd. ed: Thousand Oaks, CA: Sage. USA: SAGE Publications, Inc.

Mulyasa, E. (2003). Manajemen berbasis sekolah. Bandung: PT Remaja Rosdakarya.

Nwakpa, P. (2015). Student personnel management: a panacea for effective secondary school administration in Nigeria. Journal of Research in Humanities and Social Science, 3(5), 62-64.

Paletta, A. (2011). Managing student learning: Schools as multipliers of intangible resources. Educational Management Administration \& Leadership, 39(6), 733750. doi: https://doi.org/10.1177\%2F1741143211416385

Pavletic, A. et al. (2016). Health services in boarding school. The Journal of School Nursing, 32(5), 304-314. doi: https://doi.org/10.1177/1059840516649234

Piché, G., Fitzpatrick, C., \& Pagani, L. S. (2015). Associations between extracurricular activity and self-regulation: a longitudinal study from 5 to 10 years of age. American Journal of Health Promotion, 30(1), e32-e40.. doi: https://doi.org/10.4278/ajhp.131021-QUAN-537

Pucher, K., Boot, N. \& Vries, N. (2013). Systematic review: School health promotion interventions targeting physical activity and nutrition can improve academic performance in primary- and middle school children. Health Education, 113(5), 372-391. doi: https://doi.org/10.1108/HE-02-2012-0013

Ramey, D. M. (2015). The social structure of criminalized and medicalized school discipline. Sociology of Education, 88(3), 181-201. doi: https://doi.org/10.1177/0038040715587114

Ruttoh, M. J. K. (2015). Planning and Implementation of Guidance and Counseling Activities in Secondary Schools: A Case of Kamariny Division of Keiyo District, Kenya. Journal of Education and Practice, 6(5), 1-4.

Scheel, M. J., Madabhushi, S., \& Backhaus, A. (2009). The academic motivation of atrisk students in a counseling prevention program. The Counseling Psychologist, 37(8), 1147-1178. doi: https://doi.org/10.1177/0011000009338495

Shear, B. (1965). Student management services: History and growth. Theory into Practice, 4, 133-139. doi: https://doi.org/10.1080/00405846509541963

Sillanpaa, V. (2011). Performance measurement in welfare services: a survey of Finnish organizations. Measuring Business Excellence, 15(4), 62-70. doi: https://doi.org/10.1108/13683041111184116 
Singh, A. K., \& Srivastava, S. (2013). Antecedents and Consequence of Student Engagement in an Indian Management Education Setting. Metamorphosis, 12(1), 47-64. doi: https://doi.org/10.1177/0972622520130105

Tikkanen, I. (2009). Maslow's hierarchy and students' suggestions for developing school meal. Nutrition and Food Science, 39(5), 534-543. doi: https://doi.org/10.1108/00346650910992196

Uhbiyati, N. (2015). A competency-based model of the human resource development management of ustadz at salaf boarding school. International Journal of Educational Management, 29(5), 695-708. doi: https://doi.org/10.1108/IJEM-082014-0118

White, M. A. (2004). An Australian Co-Educational Boarding School: A Sociological Study of Anglo-Australian and Overseas Students' Attitudes from Their Own Memoirs. International Education Journal, 5(1), 65-78.

Wilson, K. (1966). Educational administration. USA: Charles E. Merril Books, Inc.

Yue, A., Shi, Y., Chang, F. et al. (2012). Dormitory management and boarding students in China's rural elementary schools. China Agricultural Economic Review, 6 (3), 523-550.

Zhao, Z. (2011).A matter of money? Policy analysis of rural boarding schools in China. Education, Citizenship and Social Justice, 6(3), 237-249. doi: https://doi.org/10.1177/1746197911417415 